\title{
Cerebrospinal fluid neuron-specific enolase is decreased in multi-infarct dementia, but unchanged in Alzheimer's disease
}

\author{
RAIMO SULKAVA, * LASSE VIINIKKA, $\dagger$ TIMO ERKINJUNTTI, * RISTO ROINE* \\ From the Department of Neurology* and Childrens' Hospital, $\dagger$ University of Helsinki, Finland
}

SUMMARY Cerebrospinal fluid (CSF) levels of neuron-specific enolase (NSE) were measured in 22 patients with probable Alzheimer's disease and in 35 patients with multi-infarct dementia, and in 15 controls. CSF NSE in patients with Alzheimer's disease did not differ from those in controls. In patients with multi-infarct dementia without recent vascular events CSF NSE was lower than in controls or in Alzheimer patients. This finding is in accord with the prevailing opinion that vascular dementia is caused by multiple infarcts and not by continuous neuronal ischaemia.

Neuron-specific enolase (NSE), one of the glycolytic enzymes, has been shown to be strictly localised in neurons and neuroendocrine cells. ${ }^{12}$ NSE in cerebrospinal fluid (CSF) is a marker of active injury of the nervous system. It is raised for example in encephalitis, subarachnoid haemorrhage, acute cerebral infarct and in acute phase of multiple sclerosis. ${ }^{3}$ Data on Alzheimer's disease are conflicting: both slight elevation $^{4}$ and reduction ${ }^{5}$ of CSF NSE have been reported. NSE levels in the whole temporal lobe in Alzheimer's disease were normal. ${ }^{6}$ As regards the other major type of dementia, multi-infarct dementia, the only data available are based on a series of five patients. The results suggested that CSF NSE does not change. ${ }^{3}$

To further clarify the behaviour of CSF NSE in dementia, we measured CSF NSE in patients with Alzheimer's disease, multi-infarct dementia and their controls.

\section{Patients and methods}

Patients CSF was obtained in connection with a lumbar puncture performed for routine diagnostic purpose from 22

Address for reprint requests: Raimo Sulkava, MD, Department of Neurology, University of Helsinki, 00290 Helsinki, Finland.

Received 4 August 1987 and in revised form 4 November 1987. Accepted 11 November 1987 patients with probable Alzheimer's disease and 35 with multi-infarct dementia. The clinical criteria for Alzheimer's disease $^{7}$ and multi-infarct dementia ${ }^{8}$ used here agree with post mortem neuropathological findings in more than $80 \%$ of patients. ${ }^{910}$ All patients with multi-infarct dementia had findings on CT indicating multiple cortical or deep vascular lesions of the brain. None of them had had acute neurological symptoms of stroke during the preceding 3 months. The diagnostic assessment included in all cases clinical history, neurological examination, neuropsychological investigation, ${ }^{11}$ screening laboratory tests, electroencephalography, computed tomography (CT) of the head and investigation of CSF including CSF/serum ratio of albumin reflecting the blood-brain barrier function. White matter low attenuation on non-contrast CT scans around frontal and occipital horns, or along the bodies of lateral ventricles, was rated by a neuroradiologist without knowledge of clinical data, as absent, mild, moderate or severe. ${ }^{12}$ Cortical and central brain atrophy was estimated by visual inspection and rated as none, mild, moderate or severe. ${ }^{12}$ The degree of dementia was divided into three grades (mild, moderate and severe) according to the social competence of the patient. ${ }^{13}$ The Luria-based D-Test Battery ${ }^{11}$ was given to all demented patients. The total performance quotient was calculated from all means of neuropsychological functional categories $(0=$ no defect, $3=$ very severe defect $)$.

Control CSF was obtained from 15 outpatients of the same age without dementia or known cerebral diseases in connection with diagnostic lumbar puncture. The controls included three patients with polyneuropathy of unknown cause, two with dizziness, two with diabetes and mononeuropathy, two with tension headache, and one patient 
Table 1 Characteristics of the patients and controls

\begin{tabular}{|c|c|c|c|}
\hline & $\begin{array}{l}\text { Alzheimer's disease } \\
(N=22)\end{array}$ & $\begin{array}{l}\text { Multi-infarct dementia } \\
(N=35)\end{array}$ & $\begin{array}{l}\text { Control patients } \\
(N=15)\end{array}$ \\
\hline Age, yr mean, SEM (range) & $69 \cdot 0,1 \cdot 0(54-75)$ & $69 \cdot 7,1 \cdot 1(56-81)$ & $67 \cdot 7,1 \cdot 7(59-85)$ \\
\hline $\begin{array}{l}\text { Sex } \\
\text { male } \\
\text { female }\end{array}$ & $\begin{array}{l}10(46 \%) \\
12(54 \%)\end{array}$ & $\begin{array}{l}17(49 \%) \\
18(51 \%)\end{array}$ & $\begin{array}{l}7(47 \%) \\
8(53 \%)\end{array}$ \\
\hline $\begin{array}{l}\text { Degree of dementia } \\
\text { mild } \\
\text { moderate } \\
\text { severe }\end{array}$ & $\begin{array}{l}6(28 \%) \\
8(36 \%) \\
8(36 \%)\end{array}$ & $\begin{array}{r}13(37 \%) \\
13(37 \%) \\
9(26 \%)\end{array}$ & \\
\hline $\begin{array}{l}\text { Total performance quotients of the } \\
\text { D-Test Battery mean SEM (range) }\end{array}$ & $1 \cdot 4,0 \cdot 2(0 \cdot 3-2 \cdot 9)$ & $1 \cdot 3,0 \cdot 2(0 \cdot 2-2 \cdot 9)$ & \\
\hline
\end{tabular}

with acute virus infection, extracranial arterial venous malformation, paresis of radial nerve, hypersedimentation of unknown cause, diabetes and old heart infarct and spastic dysphonia each.

Sample collection Two $\mathrm{ml}$ of CSF was collected in polyethylene tubes after taking $4 \mathrm{ml}$ of CSF for routine purposes. The samples were stored at $-20^{\circ} \mathrm{C}$ until analysed.

Radioimmunoassay NSE was measured by radioimmunoassay utilising commercial reagents (Pharmacia, Uppsala, Sweden) at Clinical Laboratory Medix (Espoo, Finland)

Statistical analysis The two-tailed $t$ test with the conservative Bonferroni criteria, chi-square test with Yates' correction and Pearson's correlation coefficient were used in statistical comparisons. ${ }^{14}$

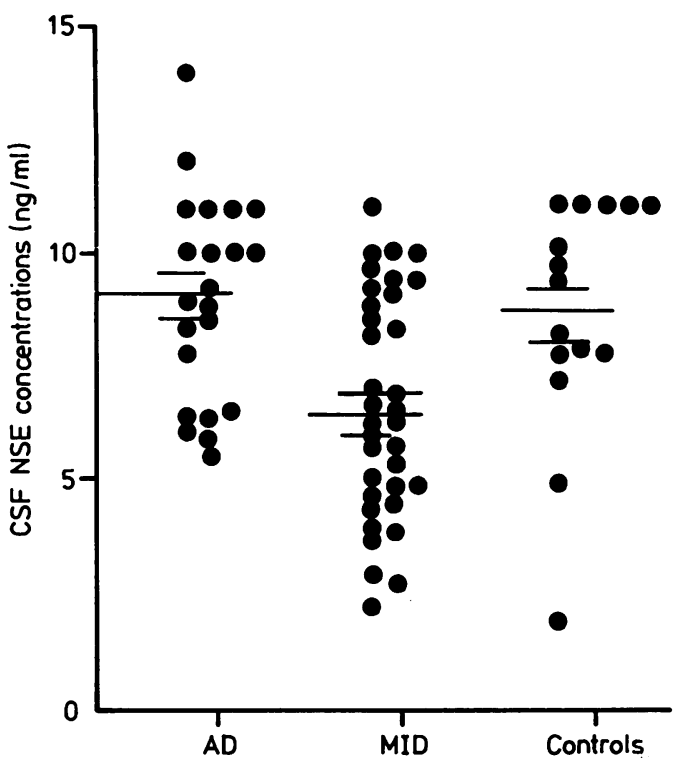

Fig 1 CSF NSE in patients with Alzheimer's disease (AD), multi-infarct dementia (MID) and controls. AD: 9.1, 0.47 $\mathrm{ng} / \mathrm{ml} \mathrm{l}^{* * *}$ (mean, SEM), MID 6.5, $0.41 \mathrm{ng} / \mathrm{ml}$,** controls $8 \cdot 6,0.67 \mathrm{ng} / \mathrm{ml}$.

$* *$ differs from controls $(p<0.01)$

*** differs from MID $(p<0.001)$

\section{Results}

The age and sex-distribution of the patients with Alzheimer's disease, multi-infarct dementia, and controls were similar, as was the severity of dementia in the dementia groups (table). The figure shows that CSF NSE was decreased in patients with multi-infarct dementia $(6 \cdot 5,0.41 \mathrm{ng} / \mathrm{ml}$, mean, SEM) as compared with controls $(8.6,0.67 \mathrm{ng} / \mathrm{ml}, \mathrm{p}<0.01)$ and with Alzheimer's disease patients $(9 \cdot 1,0.47 \mathrm{ng} / \mathrm{ml}$, $\mathrm{p}<0.001)$. The CSF NSE of controls and Alzheimer's disease patients did not differ from each other. Age, sex, degree of dementia, duration of symptoms or CSF/serum albumin ratio were not related to CSF NSE in any group.

In Alzheimer's disease white matter low attenuation, cortical and central atrophy seen on CT were not related to CSF NSE. The multi-infarct dementia patients with white matter low attenuation on CT $(n=25)$ had a significantly lower CSF NSE level than those without white matter low attenuation $(\mathrm{N}=10)$, $5.94,0.49$ and $8.1,0.53 \mathrm{ng} / \mathrm{ml}$ (mean, SEM), respectively $(p<0.05)$. Also the multi-infarct dementia patients with moderate to severe central atrophy $(\mathrm{N}=14)$ on CT had lower CSF NSE $(5.30,0.61$ $\mathrm{ng} / \mathrm{ml})$ than those with no or mild atrophy $(\mathrm{N}=21)$ $(7.37,0.48 \mathrm{ng} / \mathrm{ml})(\mathrm{p}<0.05)$. In multi-infarct dementia patients the degree of cortical atrophy was not related to CSF NSE.

\section{Discussion}

The CSF NSE levels in patients with Alzheimer's disease did not differ from those in controls. Thus our data contradict both the increased CSF NSE ${ }^{4}$ and the decreased CSF NSE ${ }^{5}$ reported earlier. In Alzheimer's disease the continuous neuronal destruction might tend to increase CSF NSE, but the decreased amount of neural tissue and its deteriorated functional activity could lower the enzyme level. Taking all this together, it seems evident that no marked change of CSF NSE exists in Alzheimer's disease.

The decrease of CSF NSE in multi-infarct dementia is a new finding. It can be explained on the basis of 
decreased amount of neural tissue as a result of preceding infarcts. The association of moderate to severe central atrophy with lower enzyme levels supports also this assumption. In Alzheimer's disease the low levels of CSF NSE due to cerebral atrophy are probably compensated by the continuous neuronal destruction.

Because it is difficult to obtain CSF samples from healthy elderly people the control group consisted of outpatients with neurological symptoms but without organic neurological changes and of those with peripheral neuropathies. CSF NSE reflects a central nervous lesion and NSE level is lower in serum than in CSF. ${ }^{15}$ Furthermore, patients with "chronic polyneuritis" 3 and those undergoing myelography ${ }^{16}$ have shown low CSF NSE values compared with patients with organic brain diseases. Thus disorders in control patients should have no effect on CSF NSE levels.

Experimental studies have shown that CSF NSE is a sensitive and reliable index of ischaemic neuronal lesions. ${ }^{17}$ However, NSE is within a few days cleared from human CSF after a stroke. ${ }^{18}$ Our patients with multi-infarct dementia had not clinically suffered from acute events due to cerebral infarcts during the preceding 3 months. If, however, they had had recent silent ischaemic episodes this might have an increasing effect on CSF NSE and does not explain the low level observed.

The observed low CSF NSE values in multi-infarct dementia support the prevailing opinion that vascular dementia is caused by multiple infarcts. ${ }^{19}$ If there was a continuous ischaemia in multi-infarct dementia, it should result in increased leakage of NSE from neural cells and in increased CSF NSE. The multi-infarct dementia patients with white matter low attenuation thought to be of vascular origin ${ }^{12}$ had the lowest levels. Thus even this change does not seem to be associated with steadily progressive ischaemic destruction of neurons.

Although the mean CSF NSE differed significantly between the dementia groups, there was a wide overlap, which limits the applicability of the assay for the differential diagnosis.

This study was supported by the Paulo Foundation and the Academy of Finland. Clinical Laboratory Medix is gratefully acknowledged for the assays of CSF NSE, Dr Leena Ketonen for rating of CT scans, and Ritva Laaksonen, M.A. and Raija Syrjäläinen, M.A. for neuropsychological testing.

\section{References}

1 Marangos PJ, Zis AP, Clark RL, Goodwin FK Neuronal, non-neuronal and hybrid forms of enolase in brain: structural, immunological and functional comparisons. Brain Res 1978;150:117-33.

2 Schmechel D, Marangos PJ, Zis AP, Brightman M, Goodwin FK. Brain enolases as specific markers of neuronal and glial cells. Science 1978;199:313-5.
3 Mokuno K, Kato K, Kawai K, Matsuoka Y, Yanagi T, Sobue I. Neuron-specific enolase and S-100 protein levels in cerebrospinal fluid of patients with various neurological diseases. J Neurol Sci 1983;60:443-51.

4 Royds JA, Davies-Jones GAB, Lewtas NA Timperley WR, Taylor CB. Enolase isoenzymes in the cerebrospinal fluid of patients with diseases of the nervous system. $J$ Neurol Neurosurg Psychiatry 1983;46:1031-6.

5 Cutler NR, Kay AD, Marangos PJ, Burg C. Cerebrospinal fluid neuron-specific enolase is reduced in Alzheimer's disease. Arch Neurol 1986;43:153-4.

6 Bowen DM, White P, Spillane JA, et al. Accelerated aging or selective neuronal loss as an important cause of dementia? Lancet 1979;i:11-14.

7 McKhann G, Drachman D, Folstein M, Katzman R, Price D, Stadlan EM. Clinical diagnosis of Alzheimer's disease: report of the NINCDS-ADRDA Work Group under the auspices of Department of Health and Human Services Task Force on Alzheimer's disease. Neurology 1984;34:939-44.

8 American Psychiatric Association. Diagnostic and Statistical Manual of Mental Disorders. 3rd ed, Washington: APA, 1980.

9 Sulkava R, Haltia M, Paetau A, Wikström J, Palo J. Accuracy of clinical diagnosis in primary degenerative dementia: correlation with neuropathological findings. J Neurol Neurosurg Psychiatry 1983;46:9-13.

10 Erkinjuntti T, Haltia M, Palo J, Sulkava R, Paetau A. Accuracy of the clinical diagnosis of vascular dementia: a prospective and post-mortem neuropathological study. J Neurol Neurosurg Psychiatry (in press)

11 Erkinjuntti T, Laaksonen R, Sulkava R, Syrjäläinen R, Palo J. Neuropsychological differentiation between normal aging, Alzheimer's disease and vascular dementia. Acta Neurol Scand 1986;74:393-403.

12 Erkinjuntti T, Ketonen L, Sulkava R, Sipponen J, Vuorialho M, Iivanainen $M$. Do white matter changes on MRI and CT differentiate vascular dementia from Alzheimer's disease? J Neurol Neurosurg Psychiatry 1987;50:37-42.

13 Erkinjuntti T, Wikström J, Palo J, Autio L. Dementia among medical inpatients. Evaluation of 2000 consecutive admissions. Arch Intern Med 1986;146:1923-6.

14 Dixon WJ, Brown MB, Engelman L, et al. BMDP Statistical Software 1985. Loss Angeles, University of California Press, 1985.

15 Scarna H, Delafosse B, Steinberg R, et al. Neuronspecific enolase as a marker of neuronal lesions during various comas in man. Neurochem Int 1982;4:405-11.

16 Royds JA, Timperley WR, Taylor CB. Levels of enolase and other enzymes in the cerebrospinal fluid as indices of pathological change. J Neurol Neurosurg Psychiatry 1981;44:1129-35.

17 Steinberg R, Gueniau C, Scarna $\mathbf{H}$, et al. Experimental brain ischemia: neuron-specific enolase level in cerebrospinal fluid as an index of neuronal damage. $J$ Neurochemistry 1984;43:19-24.

18 Hay E, Royds JA, Davies-Jones GB, Lewtas NA, Timperley WR, Taylor CB. Cerebrospinal fluid enolase in stroke. J Neurol Neurosurg Psychiatry 1984;47:724-9.

19 Hachinski VC, Lassen NA, Marshall J. Multi-infarct dementia. A cause of mental deterioration in the elderly. Lancet 1974;ii:207-10. 